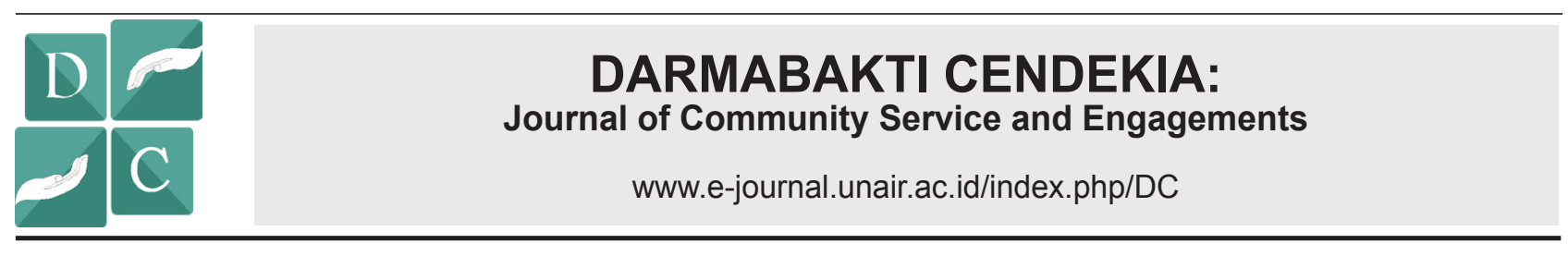

\section{INNOVATION OF MEDICINE PLANTS PROPAGATION WITH VERTICULTURE TECHNIQUES IN EFFORTS TO OVERCOME LAND DYSFUNCTIONAL IN EAST SURABAYA AREA}

\author{
INOVASI PERBANYAKAN TANAMAN OBAT DENGAN TEKNIK \\ VERTIKULTUR DALAM UPAYA MENGATASI DISFUNGSIONAL \\ LAHAN DI WILAYAH SURABAYA TIMUR
}

\author{
Junairiah $^{1^{*}}$, Tri Nurhariyati ${ }^{1}$, Listijani Suhargo ${ }^{1}$ \\ ${ }^{1}$ Department of Biology, Faculty of Science and Technology, Universitas Airlangga, Surabaya-Indonesia
}

\begin{abstract}
A B S T R A C T
Background: Keputih Village is located in eastern Surabaya. The boundary of this village is the river. Areas on the river banks are overgrown with wild plants and poorly maintained. One way to overcome the dysfunctional land around the river is by cultivating medicinal plants with verticulture techniques. Purpose: The implementation of this program is to overcome the dysfunctional land around the Keputih Village's river by cultivating medicinal plants in verticulture techniques and provide training in the manufacture of herbal products from the cultivation of medicinal plants and provide financial management training to the local residents. Method: This activity was carried out in 4 stages. Phase I was training in making pots and verticulture shelves as well as planting medicinal plants, Phase II was mentoring in the field, Phase III was training on making herbal products from plants and training on simple bookkeeping, Phase IV was product display. Results: Based on the results of this training showed that the knowledge of the participants related to the training material has increased which shown from the results of the posttest with average of 79,31 and product display. Conclusion: In this activity, beside gaining knowledge, participants can apply this knowledge to increase family income.
\end{abstract}

\section{A B S T R A K}

Latar belakang: Desa Keputih terletak di Surabaya bagian timur. Desa ini mempunyai pembatas berupa sungai. Area di pinggir sungai banyak ditumbuhi tumbuhan liar dan kurang terawat. Salah satu cara mengatasi disfungsional lahan di sekitar sungai tersebut adalah dengan budidaya tanaman obat dengan teknik vertikultur. Tujuan: Program ini dilaksanakan untuk mengatasi disfungsional lahan di sekitar sungai Desa Keputih dengan melakukan budidaya tanaman obat secara vertikultur, memberikan pelatihan pembuatan produk herbal dari hasil budidaya tanaman obat tersebut serta memberikan pelatihan manajemen keuangan kepada ibu-ibu warga Desa Keputih. Metode: Kegiatan ini dilaksanakan dalam 4 tahap kegiatan. Tahap I adalah pelatihan pembuatan pot dan rak vertikultur serta penanaman tanaman obat, tahap II pendampingan di lapangan, tahap III pelatihan pembuatan produk herbal dari tanaman serta pelatihan pembukuan sederhana, tahap IV adalah display produk. Hasil: Berdasarkan hasil pelatihan menunjukkan bahwa pengetahuan peserta terkait materi pelatihan pembuatan pot dan budidaya tanaman obat dengan teknik vertikultur, pembuatan produk herbal dan manajemen keuangan mengalami peningkatan yang ditunjukkan dari hasil postest dengan rerata nilai 79,31 dan display produk. Kesimpulan: Pada kegiatan ini peserta selain mendapatkan pengetahuan juga dapat dapat menerapkan ilmunya untuk meningkatkatkan pendapatan keluarga.
Scope:

Applied Science
Keywords:

Herbal products, Medicinal plants, Verticulture
Kata kunci:

Produk jamu, Tanaman obat, Vertikultur 


\section{PENDAHULUAN}

Desa Keputih merupakan kawasan yang terletak di Surabaya timur, Kecamatan Sukolilo. Desa ini mempunyai pembatas berupa sungai (Gambar1). Area dipinggirsungaibanyakditumbuhi tumbuhan liar dan kurang terawat dengan baik, padahal jika dilakukan budidaya tanaman obat dapat mengatasi disfungsional lahan di sekitar sungai tersebut. Selain itu hasil panen tanaman obat dapat dimanfaatkan oleh ibu-ibu warga Desa Keputih untuk pembuatan jamu herbal yang bisa dijual sehingga dapat meningkatkan kesejahteraan warga sekitar. Vertikultur merupakan alternatif teknik budidaya yang bisa dimanfaatkan untuk mengatasi permasalahan tersebut.

Vertikultur adalah sistem budidaya pertanian yang dilakukan secara vertikal atau bertingkat (Rasapto, 2006; Nurmawati and Kadarwati, 2016; Hadi et al., 2017). Sistem ini merupakan konsep penghijauan yang cocok untuk daerah perkotaan dan lahan terbatas. Diharapkan dengan pertanian menggunakan vertikultur tidak hanya sebagai sumber pangan tetapi juga sebagai sumber obat dan dapat menciptakan suasana alam yang menyenangkan (Lukman, 2011).

Budidaya tanaman obat dengan vertikultur mempunyai keunggulan yaitu kualitas produksi lebih baik dan lebih bersih. Selain itu, kuantitas produksi lebih tinggi dan kontinuitas produksi dapat dijaga. Hal ini dapat menunjang pendapatan, dapat menjadi lahan bisnis, dan mempercantik lingkungan.

Mitra dalam Program Kemitraan Masyarakat (PKM) ini adalah ibu ibu PKK yang ada di Desa Keputih. Permasalahan yang dihadapi oleh mitra adalah adanya disfungsional lahan sempadan sungai sehingga lingkungan menjadi tidak nyaman. Selain itu, mitra menginginkan pemasukan tambahan sehingga dapat membantu untuk meningkatkan kesejahteraan masyarakat.

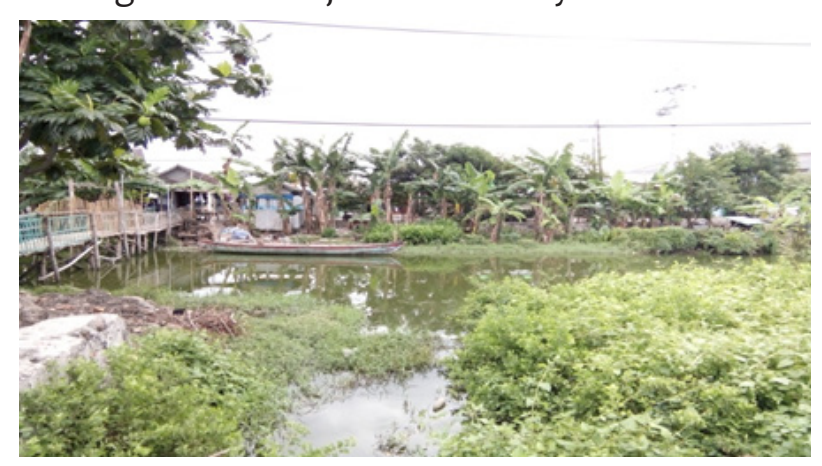

Gambar 1. Kawasan sungai di Desa Keputih

Secara umum ibu-ibu PKK yang tinggal di desa ini adalah ibu rumah tangga. Permasalahan yang dihadapi oleh mitra selain adanya disfungsional lahan sungai di Desa Keputih adalah permasalahan ekonomi ibu-ibu rumah tangga. Berdasarkan peninjauan tersebut, permasalahan mitra yang harus segera ditangani adalah aspek budidaya, produksi dan manajemen. Aspek budidaya meliputi: 1) pelatihan pembuatan rak vertikultur, 2) pelatihan penanaman tanaman obat, dan 3) pelatihan pemeliharaan tanaman. Aspek produksi meliputi pelatihan pembuatan produk dari bahan tanaman obat. Aspek manajemen meliputi pelatihan tentang manajemen keuangan.

\section{METODE}

Pemberian materi pelatihan (1) pelatihan tentang pembuatan rak vertikultur dengan menggunakan berbagai bahan dengan metode ceramah, diskusi, peragaan dan praktek langsung pembuatan vertikultur, (2) pelatihan penanaman dan pemeliharaan tanaman obat dengan menggunakan berbagai bahan dengan metode ceramah, diskusi, peragaan dan praktek langsung pembuatan vertikultur, (3) pelatihan pembuatan produk dari bahan tanaman obat dengan metode ceramah, diskusi, peragaan dan praktek langsung. Peserta diberikan materi tentang pembuatan jamu sirih, kunyit asam, temulawak, dan sebagainya, (4) pelatihan manajemen keuangan dengan metode ceramah, diskusi, peragaan dan praktek. Peserta diberikan materi tentang pemasukan dan pengeluaran keuangan.

\section{Rancangan Evaluasi}

Untuk mengevaluasi keberhasilan program pengabdian masyarakat Program Kemitraan Masyarakat dilakukan dengan melaksanakan pelatihan, penyuluhan dan pendampingan di Desa Keputih, Kecamatan Sukolilo, Surabaya. Rancangan evaluasi dilaksanakan dengan cara (1) menguji dengan melakukan pretest dan postest kemampuan pengetahuan tentang budidaya tanaman dengan teknik vertikultur, (2) menguji kemampuan pembuatan vertikultur, (3) menguji kemampuan pembuatan produk berupa jamu dan simplisia, (4) menguji pengetahuan tentang manajemen keuangan.

\section{HASIL DAN PEMBAHASAN}

Kegiatan pengabdian masyarakat PKM Inovasi Perbanyakan Tanaman Obat dengan Teknik Vertikultur Untuk Mengatasi Disfungsional Lahan di Wilayah Surabaya Timur dilaksanakan dalam dua tahap. Tahap pertama telah dilaksanakan pada tanggal 4 Agustus 2019 (Gambar 2). Kegiatan yang dilaksanakan terdiri atas pretest, pemberian materi berupa ceramah dan tanya-jawab tentang pelatihan pembuatan pot vertikultur dan pelatihan 
penanaman dengan teknik vertikultur. Kegiatan ditutup dengan postest.
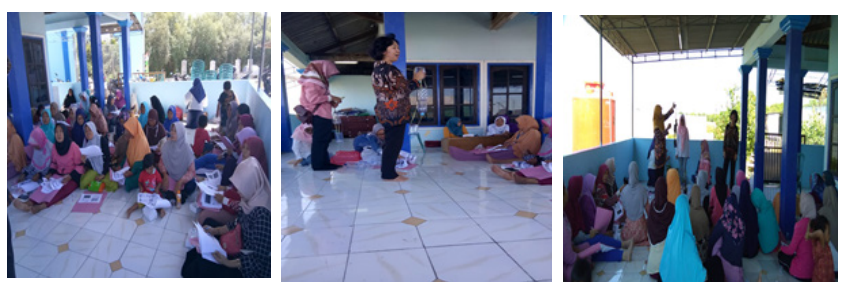

Gambar 2. Penyampaian materi pembuatan pot dan penanaman dengan teknik vertikultur

Sebelum penyampaian materi, semua peserta diberikan pretest untuk mengetahui pengetahuan awal dari peserta tentang vertikultur. Hasil dari pretest dan postest terdapat pada Gambar 3.

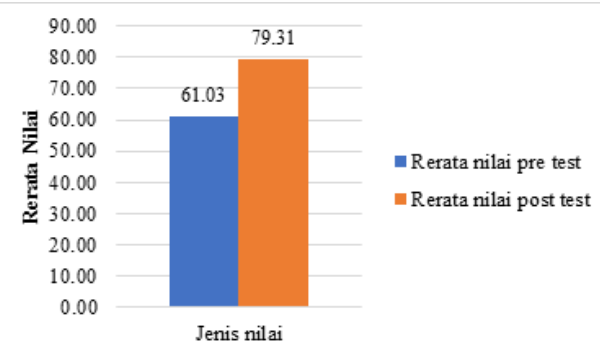

Gambar 3. Rerata nilai pretest dan postest

Penyampaian materi berupa ceramah dan demo, kemudian peserta diberikan bantuan dana untuk pembuatan pot dan penanaman dengan teknik vertikutur ini. Tanaman yang digunakan adalah berupa tumbuhan obat yaitu sirih hijau, sirih merah dan sirih hitam, serta lengkuas, kunyit putih, kunyit kuning dan jahe.

Kegiatan selanjutnya adalah penyampaian materi tentang pelatihan pembuatan produk dari tumbuhan obat dan pelatihan pembukuan sederhana tentang usaha penjualan jamu yang diadakan pada tanggal 29 September 2019. Sebelum pemaparan materi dilakukan pretest dan setelah penyampaian materi ditutup dengan postest. Hasil pretest menunjukkan rerata nilai 57,93 dan rerata postest adalah 70,34. Kegiatan tahap II terdapat pada Gambar 4.
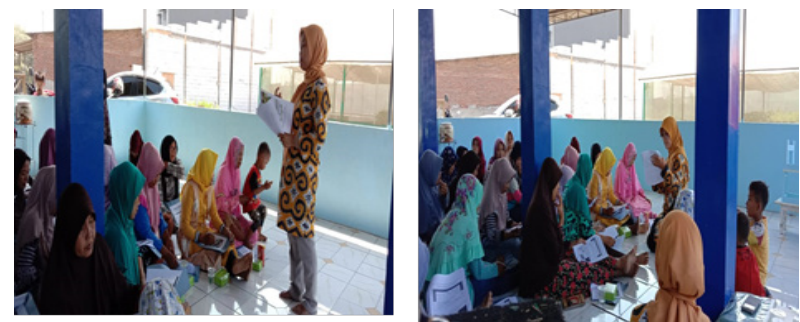

Gambar 4. Penyampaian materi pembuatan produk dan pembukuan sederhana

Kegiatan selanjutnya pada tahap keempat adalah evaluasi kegiatan, yaitu dilakukan penilaian terhadap hasil pembuatan dan penanaman pot vertikultur. Kategori penilaian meliputi keragaman tanaman (tanaman yang ditanam beragam atau tidak), kesuburan tanaman (tanaman tampak sehat dan kokoh), keindahan taman (keserasian penataan tanaman yang bagus dipandang), keasrian taman, kebersihan taman (jarak tanaman yang ditanam proporsional atau tidak bertumpuk), kelengkapan taman (kelengkapan atribut untuk menanam), fungsi tanaman sebagai obat (pemanfaatan tanaman sebagai tanaman obat), kreativitas (pemanfaatan kembali barang yang tidak terpakai), kekompakan kelompok (kerjasama antar anggota kelompok) dan antusias kelompok (semangat kelompok dalam menanggapi setiap kegiatan).

Untuk pembuatan produk jamu, kriteria penilaian meliputi keragaman jamu (jenis jamu yang diproduksi beragam), komposisi bahan (bahan tanaman obat yang digunakan untuk memproduksi jamu, cita rasa jamu rasa jamu yang diproduksi segar dan kaya akan rempah), kebersihan jamu (proses produksi jamu terjaga kebersihannya),khasiatjamu(jamuyang diproduksi memiliki khasiat yang baik bagi kesehatan tubuh), penyajian jamu untuk konsumen (kemasan jamu rapi dan informatif bagi konsumen), kreativitas (desain dan wadah kemasan serta label jamu yang menarik konsumen), dan kekompakan kelompok (kerjasama antar anggota kelompok). Untuk pembuatan pot dan penanaman dengan pot vertikultur diikuti oleh 5 kelompok (Gambar 5) sedangkan untuk pembuatan jamu diikuti oleh 6 kelompok (Gambar 6).
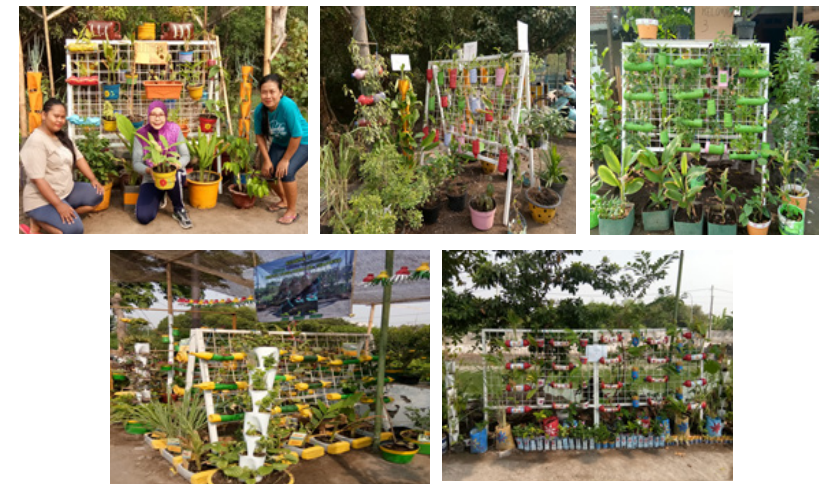

Gambar 5. Pembuatan pot dan penanaman dengan teknik vertikultur

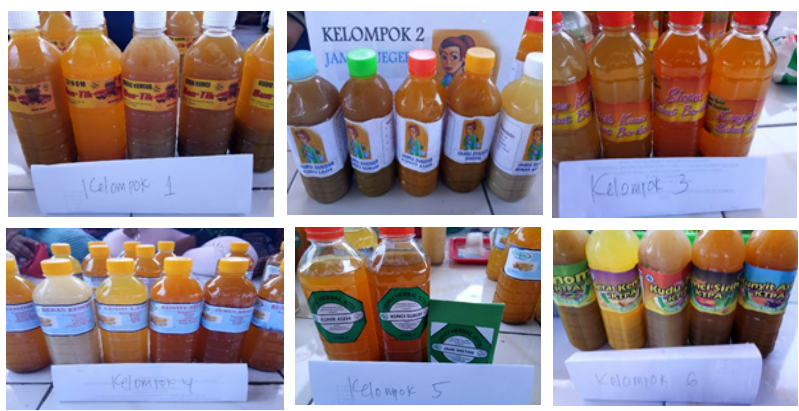

Gambar 6. Produk Jamu 
Dengan adanya kegiatan ini semoga para peserta dapat mengaplikasikan untuk budidaya tumbuhan obat serta mengolahnya menjadiproduk jamu sehingga dapat menambah pemasukan bagi keluarga. Hal ini juga dilakukan oleh ibu-ibu PKK di Kelurahan Tlogo Mas, Kecamatan Lowok Waru Malang yang membudidayakan sayuran dengan teknik vertikultur (Ningsih dkk, 2016). Demikian juga yang dilakukan penanaman tumbuhan obat dengan vertikultur yang dilakukan di Dusun Tioso (Hasyim dan Mirajuddin, 2013).

\section{KESIMPULAN DAN SARAN}

Pada kegiatan pengabdian masyarakat ini peserta mendapat pengetahuan tentang pembuatan pot vertikultur, penanaman dengan teknik vertikultur, membuat produk dari tumbuhan obat, serta manajemen keuangan. Dengan adanya kegiatan ini peserta dapat melakukan budidaya serta mengolah hasil panen tumbuhan obat untuk produk jamu sehingga dapat menambah pendapatan dari peserta.

\section{UCAPAN TERIMA KASIH}

Penulis mengucapkan terima kasih kepada semua yang telah ikut ambil bagian dalam kegiatan pengabdian masyarakat ini. Adanya bantuan dari semua pihak, akhirnya pelaksanaan kegiatan pengabdian masyarakat ini bisa berjalan dengan baik. Penulis menyatakan tidak ada konflik kepentingan dengan pihak-pihak yang terkait dalam kegiatan pengabdian kepada masyarakat ini.

\section{DAFTAR PUSTAKA}

Hadi, S. N., Rahayu, A. Y., Widiyawati, I. 2017. Penerapan Teknologi Berkebun Sayur secara Vertikultur Pada Siswa Sekolah Dasar di Purwokerto, Jawa Tengah. Panrita Abdi: Jurnal Pengabdian Kepada Masyrakat. Vol. 1(2). Pp. 114-119.

Hayim, M., dan Mirajuddin, M. 2013. Pendampingan Pembuatan Media Vertikultur untuk Penanaman Tumbuhan Obat dalam Pemaksimalan Pekarangan Rumah. Jurnal Inovasi dan Kewirausahaan Vol. 2(2). Pp. 8287.

Lukman, L. 2011. Teknologi Budidaya Tanaman Sayuran secara Vertikultur. Jakarta: Kementerian Pertanian Badan Litbang Pertanian.

Ningsih, G. P., Rasyid, H., dan Muhidin. 2016. IBM Budidaya Tanaman Sayuran secara Vertikultur.
Seminar Nasional dan Gelar Produk; Malang, Indonesia.

Nurmawati, dan Kadarwati, S. 2016. Vertikultur Media Paralon sebagai Upaya Memenuhi Kemandirian Pangan di Wilayah Peri Urban Kota Semarang. Jurnal Pendidikan Sains Vol. 4(2). Pp. 19-25.

Rasapto, W. 2006. Budidaya Sayuran dengan Vertikultur. Prosiding Temu Teknis Nasional Tenaga Fungsional Pertanian; Bogor, Indonesia. 